\title{
Współczynnik ściśliwości skał i płynów - parametr petrofizyczny, który należy uwzględnić, czy który można pominąć w charakterystyce złóż surowców płynnych?
}

\begin{abstract}
W niniejszej pracy przedstawiono możliwości zastosowania parametru ściśliwości w inżynierii naftowej. Wskazano obszary i warunki, w których pominięcie tego parametru może skutkować znacznymi błędami w obliczeniach inżynierskich. Ponadto zaprezentowano wyznaczone przykładowe zależności ściśliwości solanki od ciśnienia, jak również zmiany objętości porowej przy zmiennej wartości ciśnienia porowego i ciśnienia nadkładu wykonane na próbkach skał i płynów złożowych $\mathrm{z}$ utworów dolomitu głównego.
\end{abstract}

Słowa kluczowe: ściśliwość, objętość porowa, ściśliwość solanki, ściśliwość skał.

\section{Compressibility - petrophysical parameter which should be considered or might be omitted in reservoir characterization?}

This paper presents the possibilities of compressibility application in reservoir engineering. Areas and conditions in which omitting of that petrophysical parameter may result in significant errors in engineering calculations were indicated. Moreover, exemplary dependencies of brine compressibility and variations of pore volume with pore pressure and confining pressure for main dolomite samples were presented.

Key words: compressibility, pore volume, brine compressibility, rock compressibility

\section{Wprowadzenie}

Pojęcie ściśliwości, zarówno płynów, jak i skał, ma istotne znaczenie w wielu naukowych gałęziach wiedzy, do których należy między innymi inżynieria złożowa, geologia, hydrogeologia, geotechnika czy górnictwo. Parametr ten wykorzystywany jest w obliczeniach dynamicznych zasobów surowców płynnych, obliczeniach ciśnienia porowego, w górnictwie naftowym, ocenie ciśnienia hydraulicznego w strefie ruchów tektonicznych itp.

W celu oszacowania deformacji skał pod wpływem zmian naprężeń efektywnych działających na skałę stosowana jest teo-

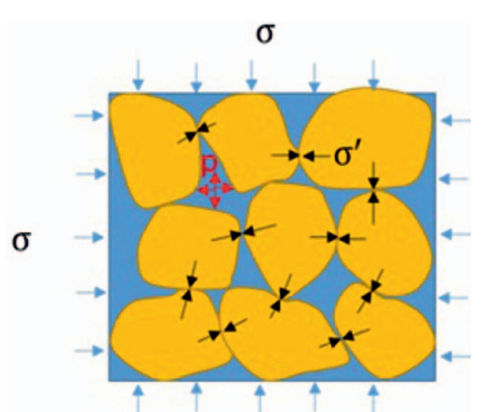

Rys. 1 Naprężenie całkowite $(\sigma)$ i naprężenie efektywne $\left(\sigma^{\prime}\right)$ będące wynikiem działania ciśnienia porowego $p$ ria poroelastyczności. W złożach węglowodorów zmiany te mogą być wynikiem obniżenia ciśnienia porowego płynu $p$ (rysunki 1 i 2), tj. ciśnienia wywieranego przez płyn wypełniający przestrzeń porową na danej głębokości, przeciwdziałającego wartości naprężeń podstawowych [16], na skutek sczerpania złoża lub jego wzrostu w wyniku np. stosowanych metod wtórnych eksploatacji.Sczerpanie zwiększa

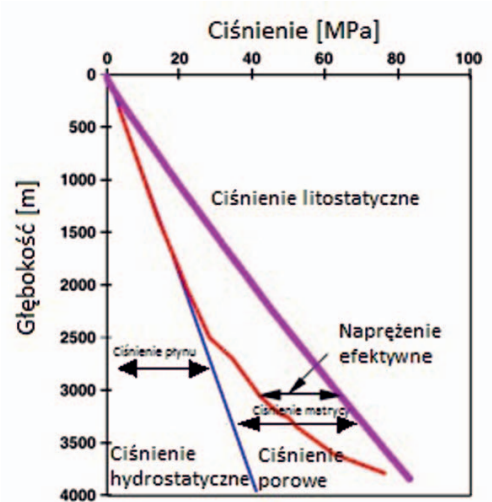

Rys. 2. Przykładowy rozkład ciśnienia porowego, litostatycznego i pionowego naprężenia efektywnego w funkcji głębokości 
średnią wartość naprężeń efektywnych działających na układ ziaren, z których zbudowana jest skała złożowa, co w efekcie prowadzi do zwiększenia stopnia kompakcji i zmniejszenia porowatości. Z kolei wzrostowi ciśnienia porowego towarzyszy spadek gęstości objętościowej skały, a tym samym wzrost porowatości. Wpływ zmian ciśnienia porowego na odkształcenia złoża i kompakcję jest istotny na każdym etapie wiercenia (zagrożenie związane np. z wyboczeniem otworu) i eksploatacji złoża (zmiana parametrów petrofizycznych, zmiana energii złożowej, piaszczenie itp).

\section{Definicja ściśliwości}

Całkowita ściśliwość skał $C_{t}$ jest szeroko stosowana w bilansie materiałowym i definiowana jako:

$$
C_{t}=S_{o} C_{o}+S_{w} C_{w}+S_{g} C_{g}+C_{p}
$$

gdzie:

$S_{o}, S_{w}, S_{g}$ - nasycenie odpowiednio ropą, wodą i gazem,

$C_{w}-$ ściśliwość wody,

$C_{o}$ - ściśliwość ropy,

$C_{g}-$ ściśliwość gazu,

$C_{p}$ - ściśliwość formacji złożowej.

\section{Ściśliwość plynu}

Ściśliwość płynu jest cechą charakteryzującą podatność płynu na odkształcenie objętościowe przy zmianie ciśnienia. Jeżeli masa płynu o objętości $V$ w temperaturze $T$ znajduje się pod ciśnieniem $p$, to zmiana ciśnienia $\Delta p$ spowoduje zmianę objętości płynu $\Delta V$. Powszechnie znane pojęcie współczynnika ściśliwości rozumiane jest jako względna zmiana objętości do zmiany ciśnienia i przedstawiane wzorem (2):

$$
C_{f}=\frac{\Delta V}{V} \frac{1}{\Delta p}
$$

Wyraża się go w jednostce 1/Pa. Przyjmuje się, że ściśliwość wody pod wpływem przyłożonego ciśnienia jest stosunkowo nieduża, a dla większości przypadków technicznych jest tak mała, że może być pominięta. Dane literaturowe wskazują, że w temperaturze $20^{\circ} \mathrm{C}$ i przy ciśnieniu $0,1 \div 5 \mathrm{MPa}$ objętość wody zmniejsza się o 0,23\% [1].

W pracy [7] wykazano zależność ściśliwości od stężenia wodnych roztworów $\mathrm{NaCl}$ - im większe stężenie i temperatura, tym mniejsza ściśliwość. Wykazany został również brak liniowości tych zmian.

Często źródła pochodzenia podawanych wartości współczynników ściśliwości trudne są dzisiaj do odtworzenia, zwłaszcza z zakresu wysokich ciśnień [7]. Ponadto zagadnienia dotyczące ściśliwości wody i wodnych roztworów soli pod wpływem ciśnienia, jak wskazuje literatura, nie są dobrze rozpoznane. Stężenie solanki i jej skład mają znaczący wpływ na ściśliwość płynów w warunkach złożowych, co ma zasadnicze znaczenie w interpretacji wyników laboratoryjnych badań przepływów płynów w symulowanych warunkach złożowych (rysunek 3).

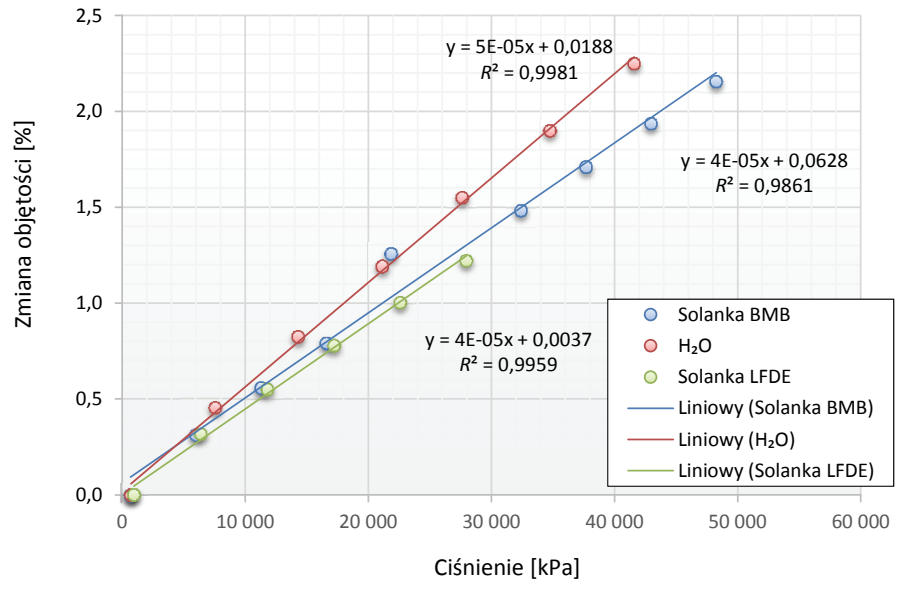

Rys. 3. Krzywa kalibracyjna wykorzystywana do pomiarów ściśliwości na tle ściśliwości wody destylowanej i solanki o niskiej mineralizacji

\section{Ściśliwość formacji}

Spowodowana przez eksploatację złoża modyfikacja naprężeń efektywnych prowadzi do zmiany objętości przestrzeni porowej. Parametrami opisującymi te zmiany są współczynniki ściśliwości. Jak było wspomniane we wstępie, rzetelne oszacowanie współczynnika ściśliwości jest szczególnie istotne podczas szacowania zasobów, utrzymywania produkcji, określenia mechanizmu wyporu, jak również w trakcie szacowania kompakcji i osiadania powierzchni terenu. Ponadto rzetelnie wykonana symulacja produkcji powinna uwzględniać całkowitą ściśliwość złoża, na którą składa się ściśliwość skały (ziaren), ściśliwość przestrzeni porowej oraz ściśliwość płynu (ropa, woda złożowa, gaz).

Zasadniczo w literaturze spotykamy trzy typy ściśliwości opisujące ośrodek porowaty:

- ściśliwość objętościową $C_{b}$, która wyraża względną zmianę objętości skały,

- Ściśliwość ziarnową $C_{g}$, wyrażającą względną zmianę objętości ziaren,

- Ściśliwość przestrzeni porowej $C_{p}$, opisującą względną zmianę objętości porowej (rysunek 4).

Wartości te możemy wyznaczyć przy stałym ciśnieniu porowym lub stałym ciśnieniu nadkładu, otrzymując poniższe współczynniki:

- $C_{b c}-$ jest zmianą objętości skały $\left(V_{b}\right)$ pod wpływem ciśnienia nadkładu $\left(P_{c}\right)$ przy stałym ciśnieniu porowym $\left(P_{p}\right)$. 
Wielkość ta opisuje zatem ściśliwość szkieletu:

$$
C_{b c}=\frac{1}{V_{b}}\left(\frac{\partial V_{b}}{\partial P_{c}}\right)_{P_{p}}
$$

- $C_{b p}$ określa zmiany w objętości związane ze zmianą ciśnienia porowego przy stałym ciśnieniu uszczelnienia:

$$
C_{b p}=\frac{1}{V_{b}}\left(\frac{\partial V_{b}}{\partial P_{p}}\right)_{P_{c}}
$$

- $C_{p c}$ - wyraża zmianę w objętości porowej $\left(V_{p}\right)$ wywołaną zmianą ciśnienia nadkładu przy stałym ciśnieniu porowym:

$$
C_{p c}=\frac{1}{V_{p}}\left(\frac{\partial V_{p}}{\partial P_{c}}\right)_{P_{p}}
$$

- $C_{p p}$ - opisuje zmianę w objętości porowej wraz ze zmianą ciśnienia porowego przy stałym ciśnieniu nadkładu:

$$
C_{p p}=\frac{1}{V_{p}}\left(\frac{\partial V_{p}}{\partial P_{p}}\right)_{P_{c}}
$$

Teoretyczne zależności pomiędzy wyżej wymienionymi parametrami ściśliwości mogą być wyprowadzone przy założeniu elastyczności ośrodka i znajomości jego porowatości:

$$
\begin{aligned}
C_{b p} & =C_{b c}-C_{g} \\
C_{p c} & =\left[\frac{C_{b c}-C_{g}}{\phi}\right]
\end{aligned}
$$

oraz

$$
C_{p p}=\left[\frac{C_{b c}-(1+\phi) C_{g}}{\phi}\right]
$$

Jako że ściśliwość ziarnowa $C_{g}$ jest niewielka (dla piaskowców wynosi ona około $0,16 \cdot 10^{-6} \mathrm{ps}^{-1}\left(0,023 \cdot 10^{-6} \mathrm{kPa}^{-1}\right)$, w przypadku złóż o dużej ściśliwości parametry $C_{b c}$ i $C_{b p}$ oraz $C_{p c}$ i $C_{p p}$ można uznać za równe [10].

W warunkach laboratoryjnych, w zależności od posiadanej aparatury, ściśliwość wyznaczana jest w symulowanych warunkach złożowych lub symulowanych warunkach eksploatacji.

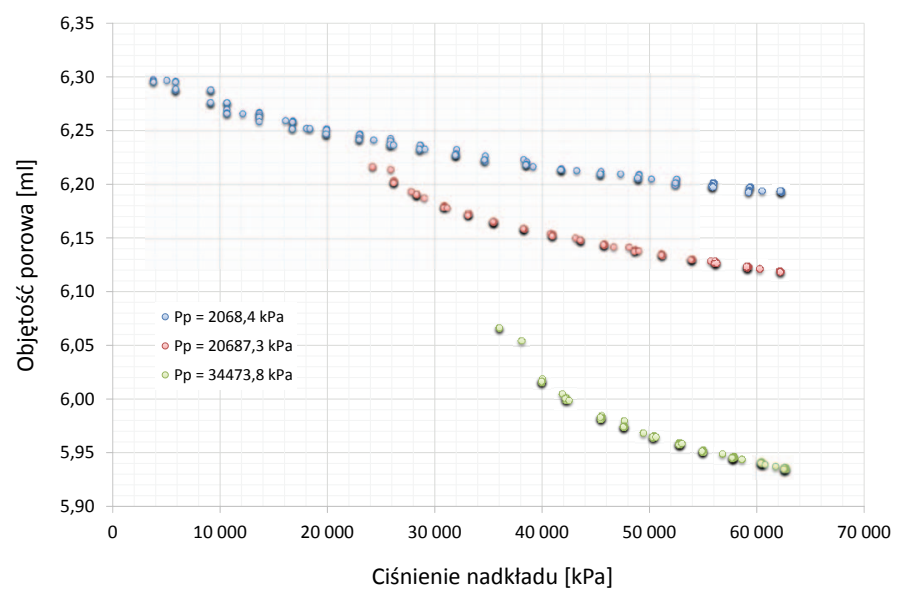

Rys. 4. Zmiana objętości porowej względem ciśnienia nadkładu (dolomit główny $\phi_{H g}=20,02 \%, P V_{\text {scisiliwość }}=6,36 \mathrm{~cm}^{3}$ )

\section{Ściśliwość skał w inżynierii złożowej}

Określenie wpływu zmian ciśnienia porowego na porowatość skały jest szczególnie istotne z punktu widzenia inżynierii złożowej, w której parametr ten wykorzystywany jest do wielu celów, opisanych w punktach poniżej:

- Wyznaczanie mechanizmu wyporu płynów złożowych

Kompakcja skał wywołana na skutek eksploatacji złoża zmniejsza objętość dostępną dla płynów porowych, w wy-

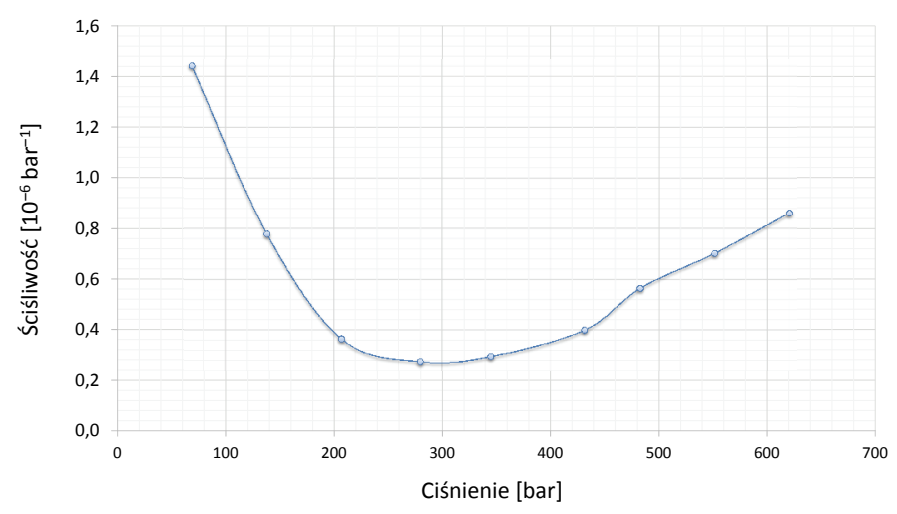

Rys. 5. Ściśliwość w funkcji ciśnienia dla złoża z Zatoki Meksykańskiej (za: [3]) niku czego wzrasta ciśnienie porowe, a zatem zmienia się energia złożowa. Mechanizm ten jest szczególnie istotny w przypadku skał o wysokim współczynniku ściśliwości, których pory wypełnione są ropą o dużej lepkości.

Kompakcyjny mechanizm wyporu może sugerować:

- ściśliwość z zakresu pomiędzy $21 \div 150 \cdot 10^{-6} \mathrm{psi}^{-1}$ $\left(304,5-2175 \cdot 10^{-6}\right.$ bar $\left.^{-1}\right)$,

- zależność ściśliwości skał od ciśnienia,

- obserwowany gwałtowny spadek ściśliwości podczas pierwszego spadku ciśnienia poniżej pierwotnego ciśnienia złożowego - zjawisko to jest związane ze zmianą ułożenia ziaren,

- wzrost ściśliwości skał przy ciśnieniu większym niż 276 bar (27,6 MPa) - zjawisko to związane jest $\mathrm{z}$ deformacją przestrzeni porowej (rysunek 5).

W przypadku złóż takich jak np. Ekofisk kluczowe jest zrozumienie wpływu kompakcji na prędkość przepływu płynu, a tym samym stopień sczerpania złoża $[2,8,15]$.

W większości złóż gazowych energia formacji jest dużo niższa niż energia gazu, przez co jest pomijana. $Z$ kolei w przypadku złóż ropy ściśliwość złoża może być znacząca w każdych 
warunkach ciśnieniowych. Wykres poniżej (rysunek 6) ilustruje zależność ściśliwości od ciśnienia złożowego dla złóż gazu. W obszarze, gdzie obie ściśliwości (formacji i płynu) mają ten sam rząd wielkości, ściśliwość formacji nie może być ignorowana.

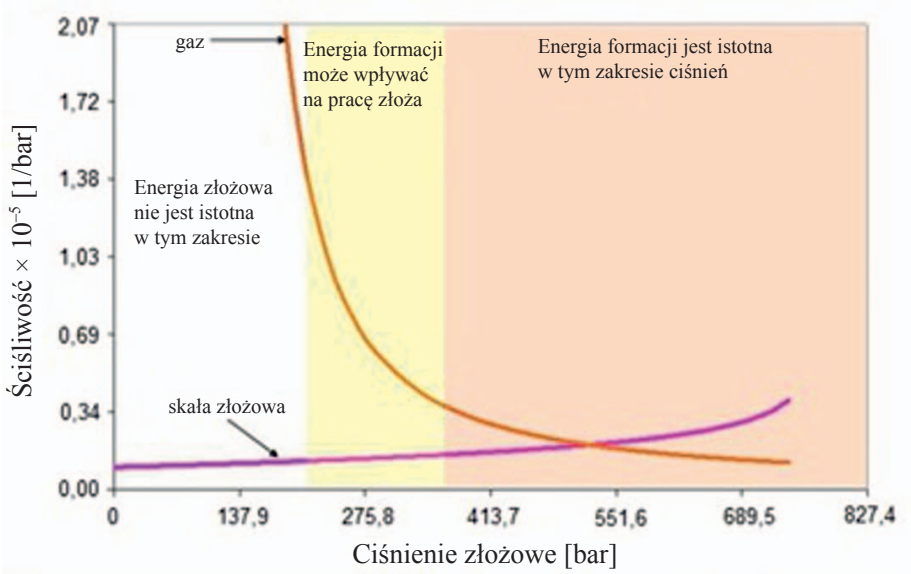

Rys. 6. Zależność ściśliwości od ciśnienia złożowego dla typowego złoża gazu ziemnego

- Szacowanie przepuszczalności w warunkach złożowych

Kompakcja może również wpływać na przepuszczalność [13]. W większości przypadków, obserwowanych zarówno w warunkach złożowych, jak i w laboratorium, kompakcja prowadzi do zmniejszenia przepuszczalności. W przypadku skał o niskiej porowatości $(<10 \%)$ może wystąpić wzrost przepuszczalności na skutek deformacji i/lub zniszczenia lepiszcza skalnego.

- Poprawne szacowanie zasobów/możliwości magazynowych Porowatość jest jednym z głównych parametrów wykorzystywanych w obliczeniach zasobów węglowodorów. Jednak nie jest on wystarczający i oszacowany bez uwzględnienia ściśliwości skały może znacząco zaburzyć wynik wyliczonych zasobów. Przykładowo, w przypadku złoża ropy o porowatości 20\% zawierającego 500 milionów baryłek ropy błąd w oznaczeniu porowatości rzędu $0,1 \%$ jest równoznaczny z 2,5 milionami baryłek ropy [12]. Oczywiście porowatość jest jednym z wielu parametrów warunkujących wydobywalne zasoby węglowodorów i zagadnienie to należy rozpatrywać holistycznie.

- Oszacowanie zmian porowatości na skutek modyfikacji ciśnienia porowego

Podczas cykli produkcyjnego i iniekcyjnego dochodzi do dużych wahań ciśnień porowych, a tym samym porowatości, które to mogą mieć znaczący wpływ np. podczas szacowania ilości zatłaczanego płynu. Dla skał zwięzłych możemy zastosować zależność [11]:

$$
\begin{gathered}
C_{p} \int_{P_{1}}^{P_{2}} \partial P=\int_{\phi_{1}}^{\phi_{2}} \frac{\partial \phi}{\phi} \\
C_{p}\left(P_{2}-P_{1}\right)=\ln \left(\frac{\phi_{2}}{\phi_{1}}\right)
\end{gathered}
$$

lub

$$
\phi_{2}=\phi_{1} \exp \left(C_{p}\left(P_{2}-P_{1}\right)\right)
$$

gdzie $\phi_{1}$ i $\phi_{2}$ to wartości porowatości odpowiednio przy ciśnieniu porowym $P_{1}$ i $P_{2}$.

- Poprawne oszacowanie możliwości magazynowej ośrodków porowatych (magazyny gazu, sekwestracja $\mathrm{CO}_{2}$, składowanie odpadów)

Współczynnik efektywności składowania zaproponowany przez $[18,19]$ wymaga znajomości zarówno współczynnika ściśliwości formacji $\left(C_{p}\right)$, jak i wody $\left(C_{w}\right)$ :

$$
E_{i}=\left(C_{p}-C_{w}\right) \Delta P
$$

gdzie: $\Delta P$ - średni wzrost ciśnienia w złożu wywołany prowadzonym zatłaczaniem.

\section{- Szacowanie zmian ciśnienia porowego}

Zmiany ciśnienia porowego na skutek eksploatacji, iniekcji i zmiany temperatury możemy oszacować za pomocą równania dyfuzji $[5,17,19]$ :

$$
\frac{\partial P_{p}}{\partial t}=\frac{k}{\phi \mu\left(C_{f}+C_{p}\right)} \nabla^{2} P_{p}
$$

gdzie:

$C_{f}-$ ściśliwość płynu porowego $[1 / \mathrm{Pa}]$,

$C_{p}$ - ściśliwość objętości porowej w jednoosiowym systemie naprężeń $[1 / \mathrm{Pa}]$,

$P_{p}$ - ciśnienie porowe $[\mathrm{Pa}]$,

$\mu$ - lepkość [Pas],

$k$ - przepuszczalność [mD].

- Przewidywanie możliwości piaszczenia odwiertów

Empiryczna korelacja napływu piasku do odwiertu, modułu sprężystości postaciowej oraz współczynnika ściśliwości objętościowej pozwoliły na określenie granicy piaszczenia odwiertu [6] na poziomie:

$$
\frac{G}{C_{b}}=0,8 \cdot 10^{12} p s i^{2}
$$

oraz wysokiego prawdopodobieństwa piaszczenia:

$$
\frac{G}{C_{b}}<0,7 \cdot 10^{12} p s i^{2}
$$


- Szacowanie przepuszczalności węgli i produkcji metanu z pokładów węgla

W celu zamodelowania zmian ściśliwości objętości porowej węgli towarzyszących zmiennym naprężeniom efektywnym stosuje się ekspotencjalne równanie spadku współczynnika ściśliwości objętości porowej w postaci:

$$
C_{p}=\frac{C_{0}}{\alpha \Delta \sigma}\left[1-e^{-\alpha \Delta \sigma}\right]
$$

Zmiana przepuszczalności z kolei zależy od wartości przepuszczalności początkowej, współczynnika ściśliwości i zmiany naprężeń efektywnych od warunków początkowych $[9,14]$ :

$$
k=k_{0} e^{-C_{p} \Delta \sigma}
$$

W zależności od zastosowania stałej lub zmiennej wartości współczynnika ściśliwości możemy otrzymać zupełnie odmienne wartości przepuszczalności.

- Szacowanie osiadania lub wypiętrzania terenu pod wptywem eksploatacji lub iniekcji do złoża

W tym celu można wprost wykorzystać współczynnik ściśliwości objętościowej zmierzony za pomocą jednoosiowego testu ściśliwości.

Zmiana wysokości terenu $\Delta H$ wywołana średnim wzrostem ciśnienia porowego $\Delta P$ w złożu o miąższości $H$ może być wyznaczona za pomocą zależności:

$$
\Delta H=C_{b u} \Delta P H
$$

gdzie $C_{b u}$ oznacza ściśliwość mierzoną w jednoosiowym stanie naprężeń.

W przypadku sekwestracji $\mathrm{CO}_{2}$ lub iniekcji innych płynów, kiedy wzrasta ciśnienie porowe, skały mogą wykazywać większą sprężystość [4]. W przypadku gdy odpowiedź skały jest izotropowa i sprężysta, można wyprowadzić zależność pomiędzy parametrami sprężystymi i ściśliwością objętościową skały:

$$
\begin{gathered}
C_{b u}=\frac{1}{M}=\frac{E(1-v)}{((1-2 v)(1+v))} \\
C_{b c}=\frac{1}{K}=\frac{E}{(3(1-2 v))}
\end{gathered}
$$

gdzie:

$v$ - współczynnik Poissona,

$E$ - moduł Younga,

$\mathrm{K}$ - moduł sprężystości objętościowej,

$M$ - moduł sprężystości zależny od typu odkształcenia skały. Zatem w przypadku braku innych rzetelnych danych ściśliwość może być wykorzystywana jako pomocniczy parametr pozwalający oszacować parametry sprężyste skały.

\section{Podsumowanie}

W literaturze polskojęzycznej odczuwa się brak materiałów badawczych dotyczących ściśliwości skał porowatych oraz wpływu tego parametru na wartości głównych parametrów petrofizycznych, jakimi są porowatość i przepuszczalność. Celem przedstawionego przeglądu literaturowego było wskazanie obszarów i warunków, w których pominięcie parametru ściśliwości może skutkować znacznymi błędami w obliczeniach inżynierskich. Istnieje zaledwie kilka publikacji mówiących o ściśliwości skał zbiornikowych Europy Centralnej. Ponadto, jak wskazuje literatura, zagadnienia dotyczące ściśliwości wody i wodnych roztworów soli pod wpływem ciśnienia nie są dobrze rozpoznane. Przedstawione przykładowe wykresy zmiany objętości porowej i ściśliwości solanek wskazują na konieczność przygotowania bazy ściśliwości skał zbiornikowych i płynów złożowych złóż Europy Centralnej, na podstawie których możliwe byłoby wyprowadzenie modeli dla poszczególnych formacji złożowych, które pozwolą na zwiększenie dokładności symulacji produkcji oraz na dokładniejszą interpretację laboratoryjnych badań przepływów, w szczególności dla złóż zalegających na głębokościach poniżej $2500 \mathrm{~m}$.

Prosimy cytować jako: Nafta-Gaz 2018, nr 6, s. 451-456, DOI: 10.18668/NG.2018.06.05

Artykuł nadesłano do Redakcji 21.12.2017 r. Zatwierdzono do druku 19.03.2018 r.

Artykuł powstał na podstawie pracy statutowej pt.: Wybrane aspekty ściśliwości skał i jej wplywu na parametry petrofizyczne zło$\dot{z} a$ - praca INiG - PIB na zlecenie MNiSW; nr zlecenia: 15/SI/17, nr archiwalny: DK-4100-15/17.

\section{Literatura}

[1] Czetwertyński E., Szuster A.: Hydrologia i hydraulika. PWSZ, Warszawa 1971.

[2] Dake L.P.: Fundamentals of reservoir engineering. First edition. Elsevier, Amsterdam 1983.
[3] Fetkovich M.J., Reese D.E., Whitson C.H.: Application of a General Material Balance for High-Pressure Gas Reservoirs (includes associated paper 51360). SPE Journal 1998, vol. 3, nr 1, s. 3-13. 
[4] Fjaer E., Holt R.M., Raaen A.M., Risnes R., Horsrud P.: Petroleum Related Rock Mechanics. $2^{\text {nd }}$ edition, Elsevier Science 2008, vol. 53, ISBN 978-0-44450-260-5.

[5] Jaeger J.C., Cook N.G.W., Zimmerman R.W.: Fundamentals of Rock Mechanics. $4^{\text {th }}$ ed., Wiley, Oxford 2007.

[6] Khamehchi E., Reisi E.: Sand production prediction using ratio of shear modulus to bulk compressibility (case study). Egyptian Journal of Petroleum 2015, vol. 24, nr 1, s. 113-118.

[7] Koszela-Marek E.: Charakterystyka zmian ściśliwości roztworów soli $\mathrm{NaCl}$ pod wplywem wysokich ciśnień hydrostatycznych. Górnictwo i Geoinżynieria 2009, R. 33, z. 1, s. 361-367.

[8] Longuemare P.: Geomechanics in reservoir simulation. Oil and Gas Science and Technology IFP 2001, vol. 57, nr 5, s. 407-599.

[9] McKee C.R., Bumb A.C., Koening R.A.: Stress-dependent permeability and porosity fo coal and other geologic formations. SPE Formation Evaluation 1988, vol. 3, nr 1, s. 81-91.

[10] McPhee C., Reed J., Zubizarreta I.: Core Analysis: A best practice guide. Development in Petroleum Science 64, Elsevier 2015, ISBN 978-0-444-63533-4.

[11] Satter A., Iqbal G., Bucwalter J.: Practical Enhanced Reservoir Engineering: Assisted with simulation software. PennWell Corporation 2007, ISBN 978-1-59370-056-0.

[12] Schutjens P., Heidung W.: On the pore volume compressibility and its application as a petrophysical parameter. $9^{\text {th }}$ Biennial International Conference \& Exposition on Petroleum Geophysics, Hyderabad 2012

[13] Schutjens P.M., Hanssen T.H., Hettema M.H., Merour J., de Bree P., Coremans J.W.: Compaction induced porosity/ permeability reduction in sandstone reservoirs: data and model for elasticity dominated deformation. SPE Reservoir Evaluation and Engineering Journal 2004, vol. 7, nr 3, s. 202-215.
[14] Seidle J.P., Jeansonne D.J., Erickson D.J.: Application of Matchstick Geometry to stress dependent permeability in coals. SPE 24361, SPE Rocky Mountain Regional Meeting, Casper, Wyoming 18-21.05.1992, s. 433-444.

[15] Sen V., Settari T.: Coupled geomechanical and flow modeling of compacting reservoirs. The Leading Edge 2005, vol. 24, nr 12, s. 1284-1286.

[16] Słota-Valim M.: Predykcja ciśnień porowych $w$ otworach wiertniczych przewiercajacych dolnopaleozoiczne formacje tupkowe basenu battyckiego - pótnocna Polska. Nafta-Gaz 2017, nr 4, s. 219-226, DOI: 10.18668/NG.2017.04.01.

[17] Terzaghi K., Peck R.B., Mesri G.: Soil Mechanics in Engineering Practice. $3^{\text {rd }}$ ed., Wiley, New York 1996.

[18] Zhou Q., Birkholzer J.T., Tsang C-F., Rutqvist J.: A method for quick assessment of $\mathrm{CO}_{2}$ storage capacity in closed and semiclosed saline formations. International Journal of Greenhouse Gas Control 2008, vol. 2, nr 4, s. 626-639.

[19] Zimmerman R.W.: Pore Volume and Porosity Change under Uniaxial Strain Conditions. Transport in Porous Media 2017, vol. 119, nr 1, s. 481-498, DOI: 10.1007/s11242-017-0894-0.

Mgr inż. Renata CICHA-SZOT
Asystent w Zakładzie Inżynierii Naftowej.
Instytut Nafty i Gazu - Państwowy Instytut Badawczy
ul. Lubicz 25 A
31-503 Kraków
E-mail: renata.cicha@inig.pl

\section{OFERTA}

\section{ZAKŁAD INŻYNIERII NAFTOWEJ}

Zakres działania:

- $\quad$ analiza przyczyn oraz badania stopnia uszkodzenia skał zbiornikowych w strefie przyotworowej;

- $\quad$ ocena głębokości infiltracji fazy ciekłej do skał zbiornikowych;

- $\quad$ ocena wpływu roztworów soli i cieczy wiertniczych na skały ilaste strefy przyotworowej

- pomiary parametrów reologicznych cieczy i niektórych ciał stałych w zakresie temperatur od -40 do $200^{\circ} \mathrm{C}$ oraz ciśnień do 150 bar:

- badania oraz dobór cieczy roboczych i solanek do prac związanych z opróbowaniem i rekonstrukcją odwiertów;

- $\quad$ ocena stateczności ścian otworów wiertniczych;

- $\quad$ określanie zdolności produkcyjnej odwiertów;

- $\quad$ symulacja eksploatacji kawernowych podziemnych magazynów gazu w wysadach solnych z uwzględnieniem konwergencji komór;

- $\quad$ zastosowanie technologii mikrobiologicznych do stymulacji odwiertów oraz usuwania osadów parafinowych w odwiertach i instalacjach napowierzchniowych;

- $\quad$ projektowanie zabiegów mikrobiologicznej intensyfikacji wydobycia ropy (MEOR)

- $\quad$ projektowanie zabiegów odcinania dopływu wód złożowych do odwiertów;

- $\quad$ określanie nieredukowalnego nasycenia próbek skały wodą złożową;

- testy zawadniania z użyciem wody, solanki lub $\mathrm{CO}_{2}$;

- fotograficzne dokumentowanie rdzeni wiertniczych

- określanie właściwości mechanicznych oraz sejsmoakustycznych skał w próbach okruchowych

- $\quad$ analiza zjawisk migracji i ekshalacji gazu ziemnego oraz występowania ciśnień w przestrzeniach międzyrurowych

- $\quad$ modelowanie obiektów złożowych i opracowywanie specjalistycznego oprogramowania z zakresu inżynierii naftowej.

Kierownik: mgr inż. Paweł Budak

Adres: ul. Lubicz 25 A, 31-503 Kraków

Telefon: 126177665

Faks: 124303885

E-mail: pawel.budak@inig.pl

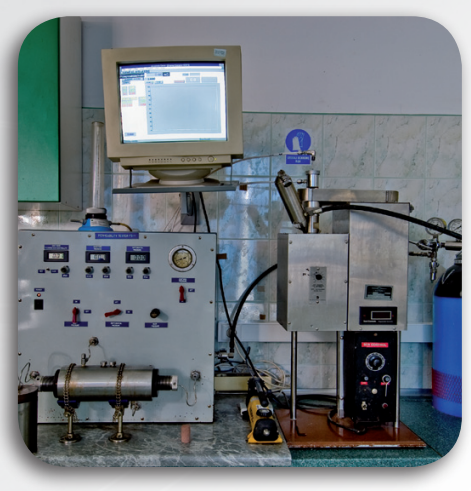

